OPEN ACCESS

Edited by: Paulo César Fonseca Giannini, University of São Paulo, Brazil

Reviewed by:

Edison Oliveira,

Federal University of Pernambuco,

Brazi

Eduardo Jiménez-Hidalgo,

University of the Sea, Mexico

${ }^{*}$ Correspondence: Lucas Henrique Medeiros da Silva

Trifilio

trifilio.lucas@outlook.com

Specialty section:

This article was submitted to Paleontology,

a section of the journal

Frontiers in Ecology and Evolution

Received: 06 December 2021

Accepted: 26 January 2022

Published: 03 March 2022

Citation:

Trifilio LHMdS, Araújo-Júnior HId, Porpino KdO and Barbosa FHdS (2022) Mammal Taphonomy in a Cave

Deposit From Quaternary of Brazil.

Front. Ecol. Evol. 10:830190.

doi: $10.3389 /$ fevo.2022.830190

\section{Mammal Taphonomy in a Cave Deposit From Quaternary of Brazil}

\author{
Lucas Henrique Medeiros da Silva Trifilio ${ }^{1,2 *}$, Hermínio Ismael de Araújo-Júnior ${ }^{2,3}$, \\ Kleberson de Oliveira Porpino ${ }^{2,4}$ and Fernando Henrique de Souza Barbosa ${ }^{2,3}$ \\ ${ }^{1}$ Programa de Pós-Graduação em Geociências, Universidade do Estado do Rio de Janeiro, Rio de Janeiro, Brazil, \\ 2 Taphonomy and Stratigraphic Paleobioloby Research Group, Faculdade de Geologia, Universidade do Estado do Rio \\ de Janeiro, Rio de Janeiro, Brazil, ${ }^{3}$ Laboratório de Paleontologia, Departamento de Estratigrafia e Paleontologia, Faculdade \\ de Geologia, Universidade do Estado do Rio de Janeiro, Rio de Janeiro, Brazil, ${ }^{4}$ Departamento de Ciências Biológicas, \\ Universidade do Estado do Rio Grande do Norte, Mossoró, Brazil
}

In Brazil, the Quaternary caves of the Brazilian Intertropical Region (BIR) host important fossiliferous deposits of terrestrial vertebrates, whose fossil content is taxonomically well known. Here, we conducted a taphonomic analysis based on macroscopic and microscopic features of 543 specimens collected in the F3 cave, a fossiliferous deposit located in the municipality of Baraúna, northeast of Brazil. This deposit encompasses 17 taxa, but it is dominated by fossils of Eremotherium laurillardi. Most bones were buried in less than a year, but the taphonomic history of this deposit was governed by alternation of dry and wet cycles. This led us to recognize four taphonomic modes, that differ according to the climatic conditions in which the bones were preserved as well as the time interval between the accumulation and the final burial of the remains.

Keywords: taphonomy, Quaternary, cave, Brazilian Intertropical Region, vertebrates

\section{INTRODUCTION}

Caves are three-dimension closed environments, quite different from the surface (Andrews, 1990), which represent some of the most fossiliferous deposits of terrestrial vertebrates (Simms, 1994). These underground geomorphologies and their associated fossiliferous content are isolated from several physical and chemical modifying agents (e.g., soil organisms, plant roots, and some scavengers)-with exception of the portions connected with the surface-besides presenting constant rates of moisture and temperature (Macdonald and Terrell-Nield, 1989; Simms, 1994). All these features turn caves into deposits with a high potential for fossiliferous preservation. Furthermore, the sediments accumulated in caves have a low risk of being disturbed in a short period, which is also an important factor for the survival of skeletal remains preserved in them (Simms, 1994).

The formation of fossil assemblages inside caves occurs through four main mechanisms, which are not mutually exclusive: (1) cave as animal's dwelling site; (2) entrapment due to falling; (3) transport by predators and scavengers, who used the cave as a shelter and accumulated skeletal parts; and (4) hydraulic transportation of bones after the death of the animal outside the cave (Andrews, 1990; Simms, 1994). Both the shape and the size of the cave entrances determine their occupation by animals, as well as whether the cave can function as a trap or is suitable for the bones to be transported into it (Andrews, 1990). 
In Brazil, caves represent one of the most important fossil accumulations of Quaternary vertebrates, especially in the Brazilian Intertropical Region (BIR), a paleobiogeographic region that includes part of the Cerrado and Caatinga biomes (Cartelle, 1999). According to recent data survey of the Centro Nacional de Pesquisa e Conservação de Cavernas/Instituto Chico Mendes de Conservação da Biodiversidade (CECAV/ICMBio), there are 21,505 cataloged caves in Brazil (CECAVCentro Nacional de Pesquisa e Conservação de Cavernas [CECAV], 2020). However, despite this huge number of recorded cavities, fossils have been recovered from only a few of them (see Cartelle, 2012). Likewise, taphonomic analyses of fossils recovered from several Brazilian caves are scarce (e.g., Auler et al., 2006; Gasparini et al., 2015; Vasconcelos et al., 2015, 2018; Maldonado et al., 2016; AraújoJúnior et al., 2017a; Buchmann et al., 2017; Silva et al., 2019a), especially in comparison to tank deposits (see Araújo-Júnior et al., 2017b), another common type of deposit of the BIR.

In this paper, we carried out a taphonomic analysis of the F3 cave, a Quaternary vertebrate cave deposit of the Lajedo da Escada karstic complex. The main objective is understanding how the biostratinomic and fossildiagenetic processes affected the formation and preservation of this important fossiliferous assemblage and point out which factors were responsible for the taphonomic alterations.

\section{GEOLOGICAL SETTING}

The F3 cave occurs in a calcareous cave system of the Lajedo da Escada Site (LES; Carvalho et al., 1966), which was developed in rocks from the Upper Cretaceous Jandaíra Formation (Apodi Group, Potiguar Basin; Carvalho, 1966; Araripe and Feijó, 1994; Pessoa-Neto et al., 2007). During the Pleistocene, outcrops of the Jandaíra Formation suffered an intense process of karstification, which generated many underground geomorphologies (Araújo-Júnior et al., 2017a).

The LES $\left(5^{\circ} 11.114^{\prime} \mathrm{S}, 37^{\circ} 43.424^{\prime} \mathrm{W}\right.$, WGS 84; Figure 1) is an area with two karstic pavements, over which seven caves (named F1-F7) were developed. All these caves are filled by a yellow calcareous clay and collapsed blocks and preserve a rich fossiliferous content including remains of avian, reptiles and small to mega-sized mammals (Carvalho et al., 1966). However, because access limitations into the caves, vertebrate fossils were collected only in five of these caves.

Among the five caves explored, F3 cave has the most abundant fossil content and was the only one submitted to a controlled fossil collection. It was initially explored during 1960's only under the taxonomic considerations (e.g., Carvalho, 1966; Porpino et al., 2009; Araújo-Júnior and Porpino, 2011), and more recently in paleopathological (Barbosa, 2013; Barbosa et al., 2014) and ichnological points of view (Araújo-Júnior et al., 2017a).

This cave presents an N-S hall connected at the top by a semicircular gap of $1.5 \mathrm{~m}$ in diameter and by two galleries of SE-NW direction. The hall has $12 \mathrm{~m}$ of horizontal development and $15 \mathrm{~m}$ of vertical development. The galleries have identical dimensions, being $10 \mathrm{~m}$ of horizontal development and $3.50 \mathrm{~m}$ of width (Carvalho et al., 1966). One of these galleries presents two infiltration sinks in its distal portions. However, due to technical limitations, their dimensions were not accurately measured. Only one of them was measured in $32 \mathrm{~m}$ of vertical unevenness, however, this measure does not correspond to its total extension (Carvalho et al., 1966; see Figure 2 for details).

Unfortunately, absolute dating is not available for the F3 cave fossils. Nevertheless, taking into consideration the most recent datings results of megafauna of the BIR (e.g., Auler et al., 2006; Silva, 2008; Dantas et al., 2013; Ribeiro et al., 2014, 2021) and considering the faunistic similarity of F3 cave with other deposits of this region, we attributed the fossils of F3 cave to the Chibanian-Northgrippian time interval (774 Ky-8.20 Ky).

\section{MATERIALS AND METHODS}

The material consists of 543 vertebrate fossils, including 497 cranial and postcranial bones and 46 teeth, which were collected in the F3 cave deposit during the 1960s by the team of Professor José Nunes Cabral de Carvalho and it is housed in the "Onofre Lopes" Vertebrate Paleontology Collection of the Museu Câmara Cascudo of the Universidade Federal do Rio Grande do Norte (MCC/UFRN). A great amount of osteoderms $(1,237)$ were also recovered, but we excluded them from the analysis because this large number of a specific type of bone element may cause analytical biases.

The taphonomic attributes and their probable causes were evaluated according to Shipman (1981); Andrews (1990), Behrensmeyer (1991); Lyman (1994), Eberth et al. (2007); Simões et al. (2010), Fernández-Jalvo et al. (2010); Fernández-Jalvo and Andrews (2016), and Araújo-Júnior and Bissaro-Júnior (2017). Macroscopically, we considered features such as the articulation of specimens, weathering marks, breakage patterns, hydraulic equivalence, trample marks, tooth marks, insect marks, transportability, abrasion, corrosion, color of bones, incrustation, mineral overgrowth, and deformation (Table 1). The taxonomic composition and ontogenetic stages were also taking in account.

The articulation depends on the number of articulated bones found in the deposit prior the collect. To evaluate the weathering, we used the six stages of decomposition and destructive surface process proposed by Behrensmeyer (1978; Table 1). Concerning to fragmentation, the breaks can be irregular, if the bone was fresh when it was broken, or have smooth borders, if the bone was broken after the fossildiagenenis (Shipman, 1981; Table 1).

The biogenic marks encompass those made by trampling, tooth, and insect. We evaluated them according to presence or absence on the bones. The trampling can produce scratches, fracturing and spatial displacement (Lyman, 1994) but only the scratches represent more reliable evidence in determining the occurrence of trampling (Fiorillo, 1989). Trample scratches are small, linear to sublinear, shallow, and subparallel traces in the bone surface and V-shaped in cross section (Fiorillo, 1987, 1988), which commonly occur in the diaphysis of long bones and present multidirectional orientation, but predominantly transverse to the longest axis of bone (Andrews and Cook, 1985; Eberth et al., 2007). 

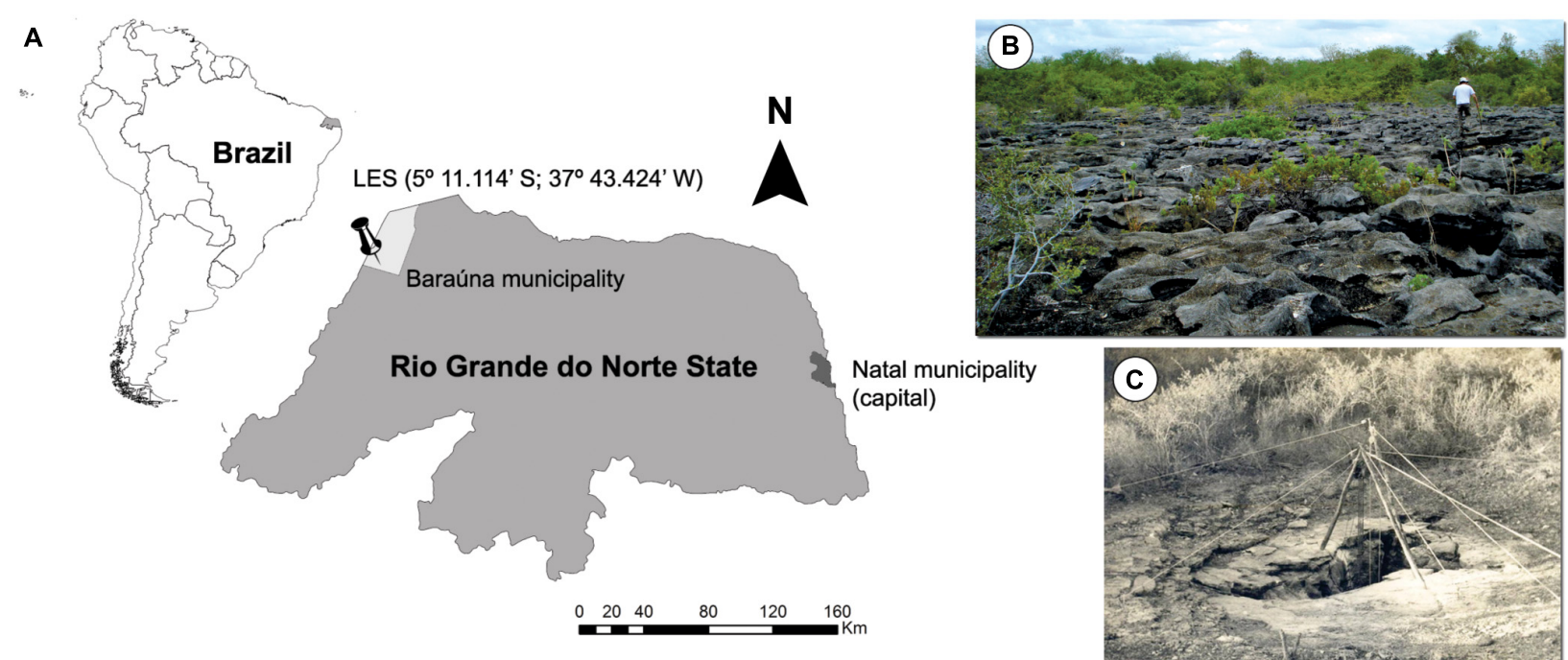

FIGURE 1 | (A) Localization map of Lajedo da Ecada Site. (B) Superior karstic pavement. (C) Entrance of cave F3.
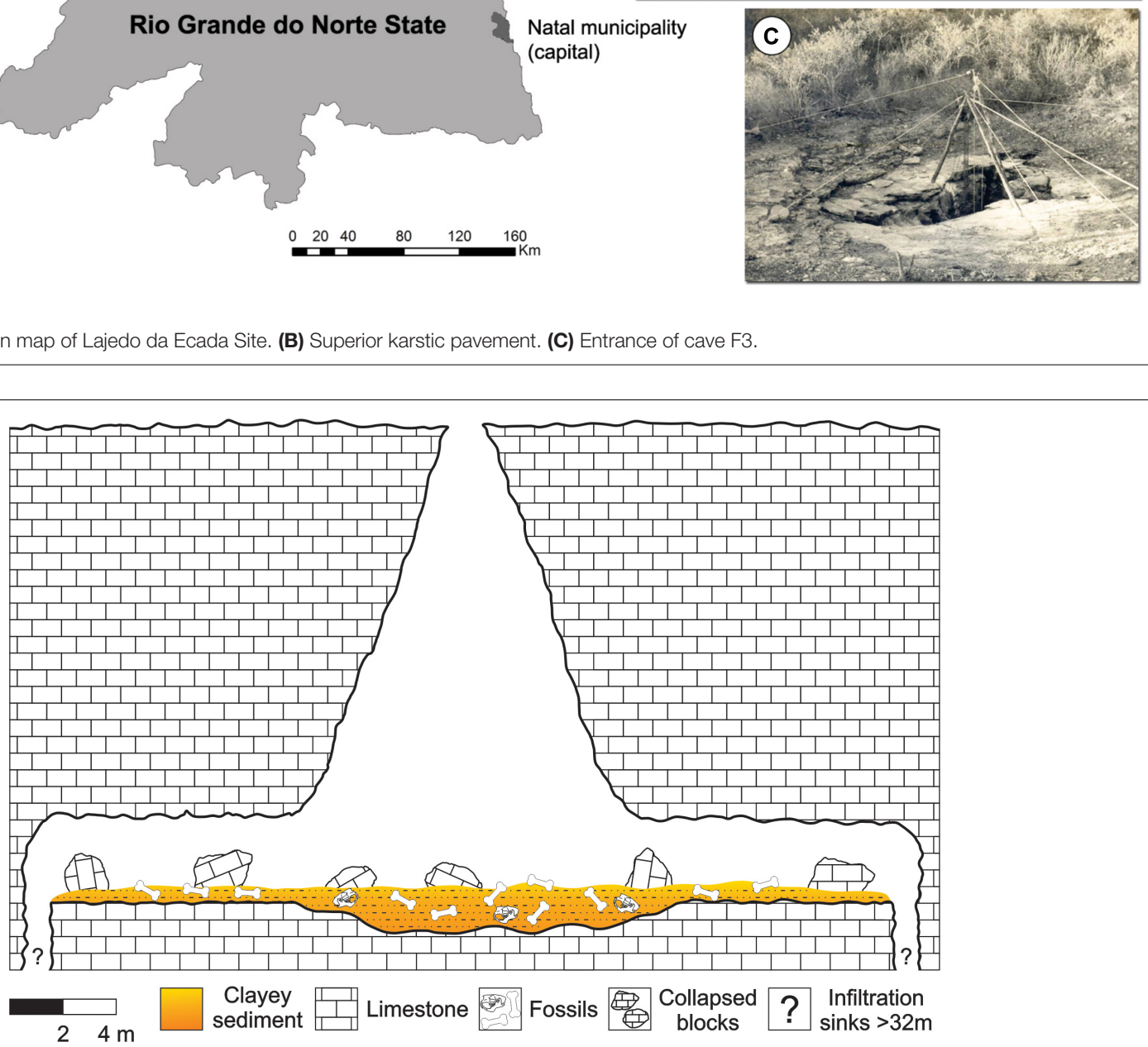

FIGURE 2 | Illustration of the speleotopography of F3 cave.

Tooth marks occur as scratches or incisions/punctures (Haynes, 1983) with U-shaped topography and usually rounded borders (Bunn, 1981) and represent a feeding interaction by predation and/or scavenging (Haynes, 1980, 1982, 1983). The insect traces comprise bioerosion and biodeposition features and were identified mainly by comparison with other works (e.g., Xing et al., 2013; Fernández-Jalvo and Andrews, 2016).

Hydraulic equivalence refers to the amount of bone particles with different sizes, density and shape that have sedimentation rate like quartz grains (Behrensmeyer, 1975). With regard to transportability of bones, we used the Fluvial Transport Index (FTI) for animals with more than $100 \mathrm{Kg}$ (Frison and Todd, 1986) and Voorhies Index (Voorhies, 1969), to those with more than 10 $\mathrm{Kg}$ and less than $100 \mathrm{Kg}$. The FTI and Voorhies Index also allows us to infer the distance of the fossiliferous assemblage from the place of death. If the remains undergone few or any transport, the assemblage is "in situ-preserved," "peripheral" if there was transport for short distance, and "ex situ-preserved assemblage" if the remains are far from the place of death (Araújo-Júnior, 2016; Table 1).

Abrasion is a mechanical process that generates polishing on bones (Fernández-Jalvo and Andrews, 2016), and it is classified in four levels of bone polishing, from no abrasion to high wear (Hunt, 1978; Fiorillo, 1988; Table 1). The corrosion is the 
TABLE 1 | Attributes and their attributions used in the taphonomic analyses.

\begin{tabular}{|c|c|c|}
\hline Attributes & Attributions & Description \\
\hline & Mid-sized & $10-100 \mathrm{Kg}$ \\
\hline & Mega-sized & Over $1,000 \mathrm{Kg}$ \\
\hline \multirow[t]{2}{*}{ Ontogeny } & Subadult & Unfused epiphysis and sutures \\
\hline & Adult & Fused epiphysis and sutures \\
\hline \multirow{2}{*}{ Physical integrity } & Partial & $50-95 \%$ of original bone \\
\hline & Complete & More than $95 \%$ of original bone \\
\hline \multirow[t]{4}{*}{ Weathering } & Stage 0 & Unaltered \\
\hline & Stage 1 & Superficial cracking \\
\hline & Stage 2 & Well-marked cracks \\
\hline & Stage 3 & Fibrous and rough texture \\
\hline & Stage 1 & Soft: Edges with little polish \\
\hline & Stage 2 & Moderate: Edges well rounded and polish in bone surface \\
\hline & Stage 3 & Intense: Edges extremely rounded and high polish in bone surface \\
\hline \multirow[t]{4}{*}{ Corrosion } & Stage 0 & Unaltered \\
\hline & Stage 1 & Soft: Corrosion does not reach the cancellous bone \\
\hline & Stage 2 & Moderate: Corrosion reaches the cancellous bone and less than $50 \%$ of the bone surface \\
\hline & Stage 3 & Intense: Corrosion reaches the cancellous bone and more than $50 \%$ of the bone surface \\
\hline \multirow[t]{3}{*}{ Incrustation } & Stage 0 & Unaltered \\
\hline & Stage 1 & Less than $50 \%$ of surface is covered \\
\hline & Stage 2 & More than $50 \%$ of surface is covered \\
\hline $\mathrm{FTI}$ & $\mathrm{FTI}<50$ & Little transportability \\
\hline \multirow[t]{3}{*}{ Assemblage } & In situ-preserved & Next to death place \\
\hline & Peripheral & Little transport from the death place \\
\hline & Ex situ-preserved & High transport from the death place \\
\hline
\end{tabular}

chemical weathering of the bone due to geochemical and/or biological processes, as algae and acid water (Fernández-Jalvo and Andrews, 2016). The intensity is measured according to the damage on the bone surface, from no damage to more than 50\% corroded (Table 1).

Incrustation is a crust on the bioclast due to activities of algae or precipitation of excess of calcium carbonate in the caves (Medeiros, 2010). It can be evaluated in three stages, according to the cover area of bone surface (Maldonado et al., 2016; Table 1). Mineral ingrowth is a process that occurs when there is an intense permineralization leading to an expansion of the tissue, causing a displacement of the anatomical structures (Araújo-Júnior and Bissaro-Júnior, 2017). Deformation is a general term for the spatial change of two or more anatomical points due intrinsic or extrinsic factors (Lyman,
1994), regardless if it is homogeneous or not (Shipman, 1981). Mineral ingrowth and deformation also were evaluated only in relation to their presence or absence. Finally, the categorization of the staining of bones follows the Munsell Book of Color (Munsell, 1994).

Concerning the microscopic analyzes, we sectioned six different fossil specimens with no anatomic information to assess the degree of permineralization into the bone microstructure. The criteria used to choose the specimens sectioned was the color variation of the bone, which covers different shades of yellow (10YR color chart; Munsell, 1994). Histological sections were performed at the Laboratório Geológico de Processamento de Amostras (LGPA) of the Faculdade de Geologia, Universidade do Estado do Rio de Janeiro (FGEL/UERJ). 
TABLE 2 | Percentage values of fossils presenting each type of break, stage of weathering, abrasion, and corrosion, and grouped with respect to FTI, Voorhies index and color.

\begin{tabular}{|c|c|c|}
\hline Feature & Stage/group & Percentage \\
\hline \multirow[t]{3}{*}{ Breakage } & Pre-fossilization & $94.2 \%$ \\
\hline & Post-fossilization & $3.2 \%$ \\
\hline & Both & $4.3 \%$ \\
\hline \multirow[t]{5}{*}{ Weathering } & Stage 0 & $80.8 \%$ \\
\hline & Stage 1 & $11.8 \%$ \\
\hline & Stage 2 & $5.7 \%$ \\
\hline & Stage 3 & $1.5 \%$ \\
\hline & Stage 4 & $0.2 \%$ \\
\hline \multirow[t]{3}{*}{ Abrasion } & Stage 0 & $51.9 \%$ \\
\hline & Stage 1 & $37.4 \%$ \\
\hline & Stage 2 & $10.7 \%$ \\
\hline \multirow[t]{4}{*}{ Corrosion } & Stage 0 & $53.6 \%$ \\
\hline & Stage 1 & $30.4 \%$ \\
\hline & Stage 2 & $14.0 \%$ \\
\hline & Stage 3 & $2.0 \%$ \\
\hline \multirow[t]{3}{*}{ FTI } & $\mathrm{FTI}<50$ & $28.8 \%$ \\
\hline & $50<\mathrm{FTI}<75$ & $19.5 \%$ \\
\hline & $\mathrm{FTI}>75$ & $51.7 \%$ \\
\hline \multirow[t]{3}{*}{ Voorhies Index } & Group I & $11.1 \%$ \\
\hline & Group | \& II & $5.56 \%$ \\
\hline & Group II & $83.3 \%$ \\
\hline \multirow[t]{4}{*}{ Color } & Light yellow (8/4) & $10.7 \%$ \\
\hline & Middle yellow (8/8) & $12.5 \%$ \\
\hline & Dark yellow (7/8) & $66.8 \%$ \\
\hline & Very dark yellow (6/8) & $9.9 \%$ \\
\hline
\end{tabular}

The specimens were sectioned across their largest axis by a diamond saw, so that it covered all types of bone tissue (compact and spongy bones). These slides were individually fixed on glass plates by a 10: $1 \mathrm{~mL}$ HY951 hardener polyester resin and subjected to the oven for a period of $24 \mathrm{~h}$. Finally, the samples were polished with carbide (320 and 600) until reaching the thickness of 50-70 $\mu \mathrm{m}$ and then covered by an acrylic coverslip. Images were taken from slides using Carl Zeiss AXIO IMAGER A2 petrographic microscope.

\section{RESULTS}

Considering all fossils that have at least one break, most bones present only pre-fossilization breaks, and, in smaller quantity, post-fossilization breaks. Most bones also do not show damage caused by weathering, abrasion, and corrosion (Figure 3 and Table 2), though some bones reached the high stages of weathering (Figure 3E) and corrosion (Figure 3L).

There are tooth marks in 29 specimens, five of which were previously described in more detail (see Araújo-Júnior et al., 2017a). The scratches occur in bones of Eremotherium laurillardi, Glyptotherium sp., Smilodon populator, Pachyarmatherium brasileinse, Cingulata indet. and Xenarthra indet (Figures 4A,B and Table 3), and the punctures were identified in bones of
E. laurillardi, Glyptotherium sp., P. brasiliense and S. populator (Figures 4C,D and Table 4).

Three specimens belonging to E. laurillardi, Palaeolama major and Mammalia indet. present insect bioturbations (Figures 5A$D$, respectively), while trample marks occur in bones of E. laurillardi, Glyptotherium sp., P. major, P. brasiliense, and Cingulata indet (Figure 5E).

There is no hydraulic equivalence between the size of the bones and the granulometry of the sediments where specimens were preserved. As mentioned in Geological Setting topic, the entire F3 cave is filled by clay, which was transported from the surface into the cave and is product of the erosion of the limestone, collapsed blocks from roof, and fossils.

To large and megammamals ( $>100 \mathrm{Kg}$ ), the FTI values shows that more than half of the bones eligible for this analysis belong to the most transportable group (FTI > 75; Table 2). To medium-sized mammals $(10-100 \mathrm{Kg}$ ), the Voorhies Index presented a dominance of bones of medium transportability (Group II; Table 2).

Deformation occurred only in a femur assigned to P. brasiliense (MCC 1145-V). shortening the cranial-caudal axis and stretching the proximal-distal and medial-lateral axes (Figures 6A,B), making it thinner and more elongated than a non-deformed femur.

Regarding the fossildiagenetic evidence, they include bones with different colors and the presence of permineralization, incrustation and mineral overgrowth. We found four shades of yellow according to chart 10YR, whose dark yellow is predominant (Figure 7 and Table 2).

All the thin sections showed that the permineralization was scarce regardless of bone color (Figure 8). Only a femur of $P$. brasiliense (MCC 1141-V) shows high levels of permineralization and mineral ingrowth (Figure 7E). Only three mandibles of $E$. laurillardi present incrustation by calcium carbonate and bone fragments in Figure 7F.

\section{TAXONOMIC COMPOSITION, ONTOGENETIC STAGES, AND ARTICULATION}

The fossiliferous assemblage of F3 cave is composed of 17 mammalian taxa (sensu Carvalho, 1966; Souza-Cunha, 1966; Damasceno, 1973; Oliveira, 1986; Porpino and Santos, 2003; Porpino et al., 2009; Oliveira et al., 2010; Araújo-Júnior and Porpino, 2011; Table 5), five of which are identified at species level. The remaining taxa were identified only at the genus (4), family (4), order (3), superorder (1) and class level (1). About $71,82 \%$ of bones correspond to adult and $27,44 \%$ belongs to subadults' animals. All bones were found disarticulated (Carvalho, 1966; Table 3).

\section{Considerations About F3 Cave Paleofauna}

Due to E. laurillardi emerging as the more abundant among 17 taxa identified, we classified the accumulation of F3 cave as 


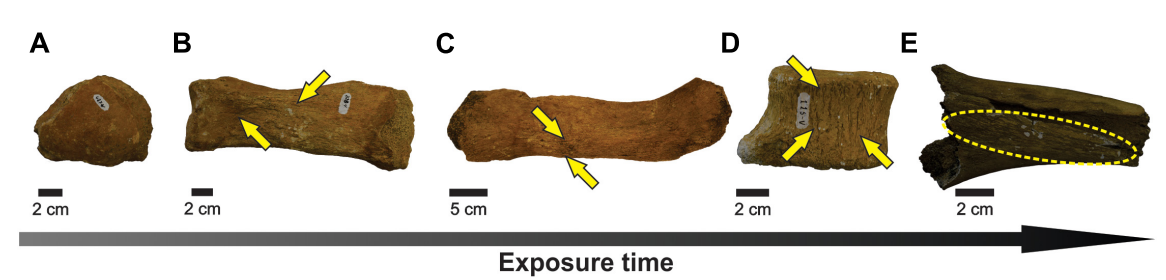

F

G

H

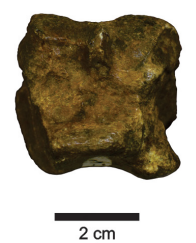

(a)

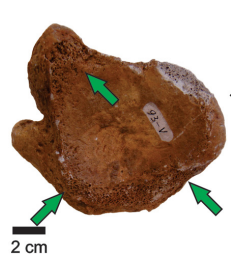

Abrasion intensity

I

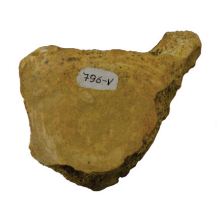

J

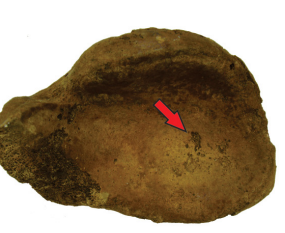

$5 \mathrm{~cm}$
K

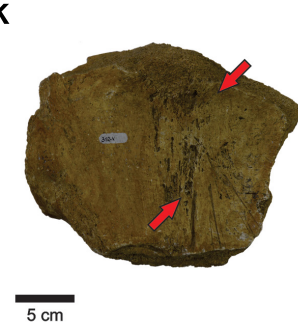

L

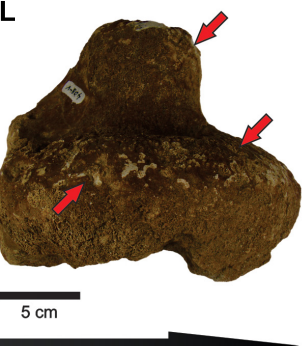

Corrosion intensity

FIGURE 3 | (A-E) Correspond to stages of physical weathering, showing the enlargement of weathering marks (pointed by yellow arrows). (F-H) Refer to stages of abrasion (abrasion marks pointed by green arrows). (I-L) Show the increasing of corrosion damage (corrosion marks pointed by red arrows). (A) Stage 0 (MCC 427-V). (B) Stage 1 (MCC 328-V); (C) Stage 2 (MCC 329-V). (D) Stage 3 (MCC 115-V). (E) Stage 4 (MCC 118-V). (F) Stage 0 (MCC 176-V). (G) Stage 1 (MCC 93-V). (H) Stage 2 (MCC 472-V). (I) Stage 0 (MCC 796-V). (J) Stage 1 (MCC 427-V). (K) Stage 2 (MCC 312-V). (L) Stage 3 (MCC 408-V).

multitaxic and monodominant. But what explains this numerical superiority of E. laurillardi in relation to the other taxa (54.1\% of sample; Table 3)?

This megatheriid is the most abundant taxon in Rio Grande do Norte State deposits, occurring in at least 14 fossil assemblages, many of which are close to the F3 cave (see Carvalho et al., 1966; Santos et al., 2002; Porpino et al., 2007; Araújo-Júnior and Porpino, 2011), and was likely the most abundant mammal in the Brazilian Pleistocene biocoenoses (Santos et al., 2002; Araújo-Júnior et al., 2013).

It is also important to consider that the bones of megatheriids do not have medullar channel, which gives them a higher resistance to destructive processes (Santos et al., 2002; AraújoJúnior et al., 2015). So, the abundance of E. laurillardi in Pleistocene deposits combined with the high structural resistance of its bones would explain the dominance of this taxon in F3 cave assemblage. An alternative hypothesis is that the cave was a dwelling site for this animal, but we can discard it for two reasons: (1) the present entrance has only $1.5 \mathrm{~m}$ in diameter, a limiting factor for an animal with $6,650 \mathrm{Kg}$ body mass (sensu Dantas et al., 2017); and (2) the cave is not suitable to dietary habits of megatheriids (plants and grasses, see Dantas et al., 2017; Silva et al., 2019b).

\section{BIOSTRATINOMY}

As most remains were not articulated, the carcasses probably undergone high energetic conditions and/or a delayed burial after death of animals (Behrensmeyer, 1991). However, this delayed burial was long enough only to disarticulate the carcasses. The rarefaction of weathering marks implies that most bones became exposed in surface for less than a year (Behrensmeyer, 1978, 1991). Marks of abrasion, tooth, insect, and trampling are also scarce and corroborate that only the minority of bones were exposed for a long time after the animals' death (Shipman, 1981; Fiorillo, 1989; Behrensmeyer, 1991; Lyman, 1994; Holz and Simões, 2002).

The high stages of weathering weaken the bone structure, making the bones more breakable (Behrensmeyer, 1978). So, the bones that preserved this more developed weathering marks became exposed inside the cave for a longer time, because they could break after falling through the entrance. These marks generated inside the cave environment are related to periodic variations of humidification and dryness.

The dimensions of punctures found in E. laurillardi, P. brasiliense and Glyptotherium sp. indicate a large-sized producer. For the individual of Glyptotherium sp.-which also 


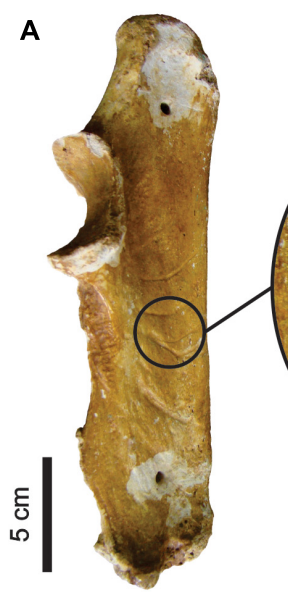

C

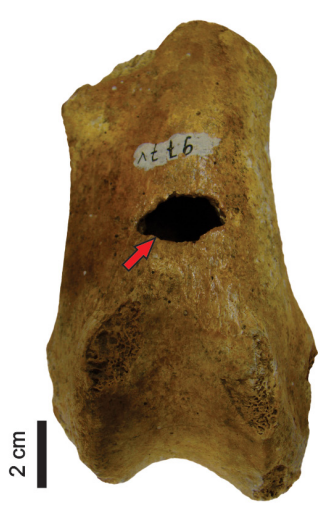

\section{B}

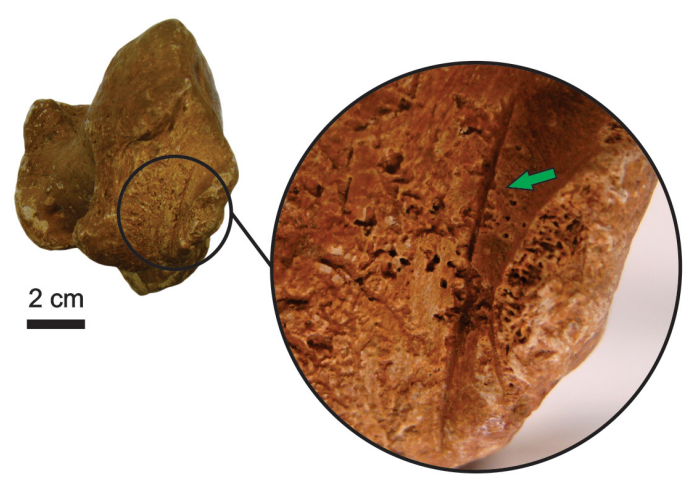

D

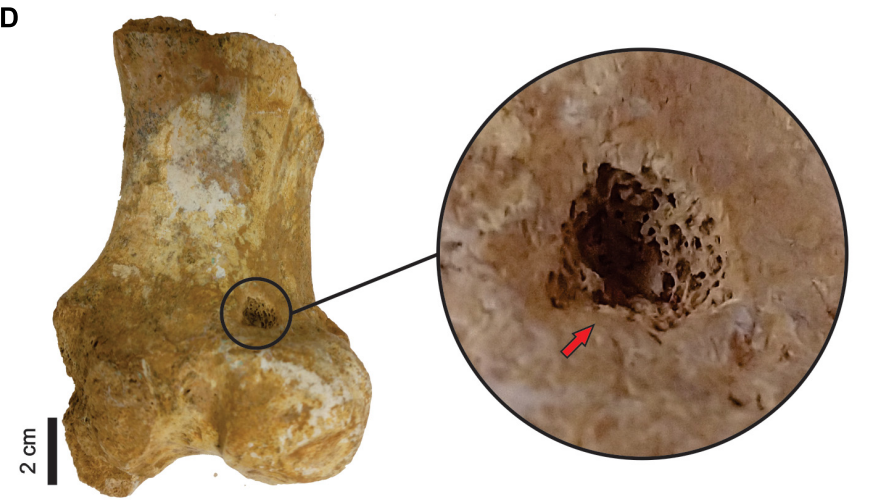

FIGURE 4 | (A) UIna (MCC 491-V) of Glyptotherium sp. with tooth marks (scratches; lateral view). (B) Calcaneus (MCC 485-V) of Glyptotherium sp. with tooth marks (scratches; dorsal view). (C,D) Femur (MCC 977-V) of P. brasiliense with tooth marks (punctures; anterior and posterior view, respectively). Yellow and green arrows point to the scratches, while red arrowns point to punctures.

TABLE 3 | Taxonomic composition and bone representativeness of each taxon in the deposit, and NISP and MNI per taxon, focusing on the quantity of adults and subadults.

\begin{tabular}{|c|c|c|c|c|}
\hline Taxa & $\begin{array}{c}\text { Taxon } \\
\text { abundance }\end{array}$ & $\begin{array}{c}\text { NISP } \\
\text { (Adult/Subadult) }\end{array}$ & $\begin{array}{c}\text { MNI } \\
\text { (Adult/Subadult) }\end{array}$ & Size \\
\hline E. laurillardi & $54.14 \%$ & $175 / 119$ & $5 / 5$ & Mega \\
\hline P. brasiliense & $8.84 \%$ & $44 / 48$ & $6 / 1$ & Medium \\
\hline Mammalia indet. & $6.45 \%$ & $29 / 6$ & * & - \\
\hline Toxodon sp. & $4.05 \%$ & $22 / 0$ & $1 / 0$ & Mega \\
\hline Cingulata indet. & $2.58 \%$ & $12 / 2$ & $1 / 1$ & - \\
\hline N. platensis & $2.03 \%$ & $8 / 3$ & $2 / 1$ & Mega \\
\hline Pampatherium sp. & $1.84 \%$ & $10 / 0$ & $1 / 0$ & Large \\
\hline Carnivora indet. & $1.47 \%$ & $8 / 0$ & $2 / 0$ & - \\
\hline Xenarthra indet. & $1.10 \%$ & $0 / 6$ & $1 / 0$ & - \\
\hline Canidae indet. & $0.18 \%$ & $0 / 1$ & $0 / 1$ & - \\
\hline Mylodontinae indet. & $0.18 \%$ & $1 / 0$ & $1 / 0$ & Mega \\
\hline
\end{tabular}

${ }^{*}$ Four bones were not identified due to the high fragmentation. Therefore, the MNI was not estimated. 
TABLE 4 | Dimensions and anatomical positions of scratch marks.

\begin{tabular}{|c|c|c|c|c|}
\hline Specimen & Scratches & Length (cm) & Thickness (cm) & Portion of bone \\
\hline MCC 441-V & Four straights & $7-15$ & 0.1 on average & Lateral portion \\
\hline MCC 816-V & Seven straights & $1.2-3.8$ & 0.1 on average & Articular surface of femoral head \\
\hline \multirow[t]{6}{*}{ MCC 485-V } & Six straights & 2.4 & 0.1 & Tuberosity \\
\hline & & 0.8 & 0.05 & Tuberosity \\
\hline & & 1.1 & 0.1 & Medial portion \\
\hline & & 1.0 & 0.1 & Medial portion \\
\hline & & 2.0 & 0.1 & Sustentaculum \\
\hline & & 0.9 & 0.1 & Sustentaculum \\
\hline \multirow[t]{2}{*}{ MCC 698-V } & Four straights & 0.75 on average & 0.1 on average & Caudal portion \\
\hline & & 1.0 on average & 0.1 on average & Ventral portion \\
\hline \multirow[t]{2}{*}{ MCC 398-V } & Two straights & 2.0 & 0.1 & Left side \\
\hline & & 1 & 0.1 & Left side \\
\hline \multirow[t]{2}{*}{ MCC 1195} & Two straights & 2.5 & 0.1 & Left side \\
\hline & & 1.25 & 0.1 & Left side \\
\hline
\end{tabular}
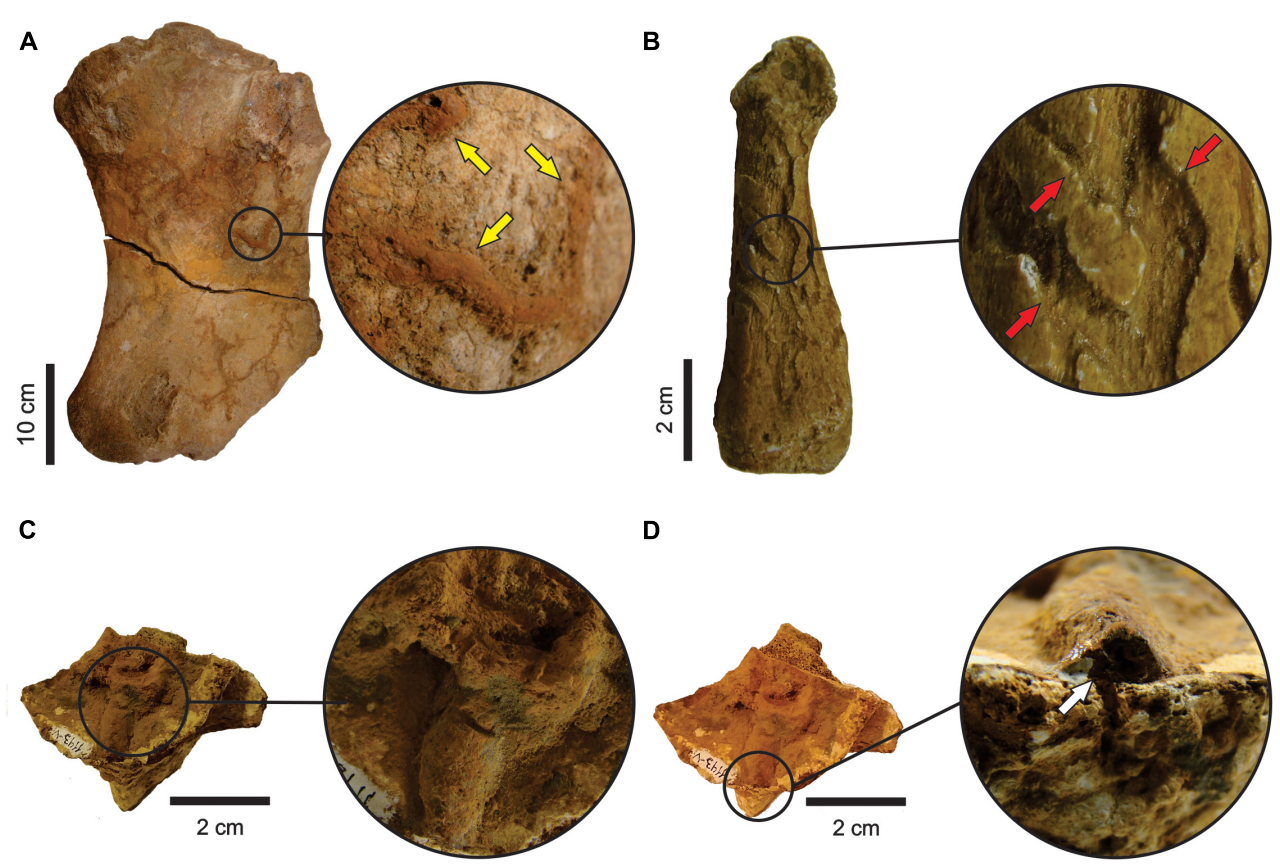

D

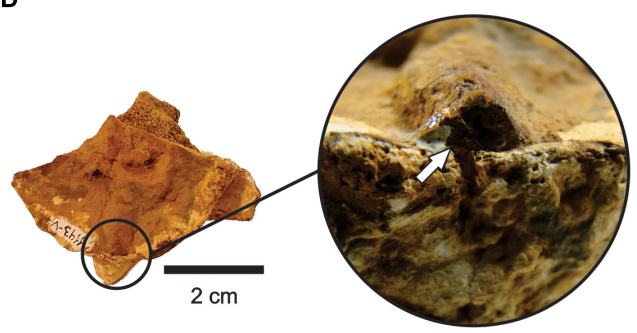

E

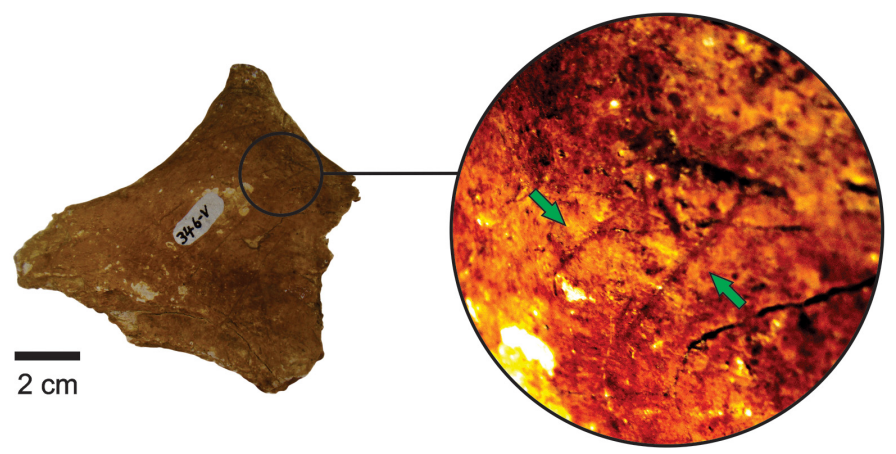

FIGURE 5 | (A) Femur (MCC 2980-V) of E. laurillardi with insect traces (anterior view). Yellow arrows point to the traces. (B) Metapodial (MCC 73-V) of P. major with insect traces (palmar view). Traces pointed by red arrows. (C,D) Pelvis (MCC 1143-V) of Mammalia indet. with insect traces (anterior view). White arrows point the traces. (E) Trample marks in a fragment of atlas (MCC 346-V) of E. laurillardi. Green arrows point the traces. 
showed scratches-we believe that both kinds of tooth marks (scratches and punctures) were produced by the same individual or a group of the same taxon of Carnivora (see Haynes, $1980,1983)$. There are scratches observed in 21 bones of E. laurillardi, Glyptotherium sp. and S. populator, and they have dimensions compatible with predators/scavengers of different sizes (see Araújo-Júnior et al., 2017a).

It is noteworthy that E. laurillardi and Glyptotherium sp. have body masses over 1,000 Kg (Dantas et al., 2017) and $700 \mathrm{Kg}$ (Dantas et al., 2020), respectively, and the teeth of a putative predator (S. populator, Cerdocyon thous, Panthera onca, or Protocyon troglodytes; see Araújo-Júnior and Porpino, 2011; Araújo-Júnior et al., 2017a) could not have reached the bone of such large-sized preys. This would be possible only if the animals were dead and in a state of necrolysis (see Haynes, 1980, 1982, 1983; Araújo-Júnior et al., 2017a), suggesting that the tooth marks have a postmortem origin. The tooth marks in $S$. populator also point to scavenger activity because this large felid was likely the top predator in the region during the Quaternary (see Dantas et al., 2020), i.e., it was the hunter and not the hunted.

And how the remains reached the deposit? For the medium-sized animals, the dominance of bones of medium transportability indicates that remains suffered a short transport from the place of death. Concerning the megamammals, the FTI analyzes point to an assemblage formed without transport of remains, i.e., in situ. However, the group of less transportable is also well represented. And the low representativeness of the intermediate group can occur because several bones within this group (e.g., scapulae, humerus and tibia) are less abundant in the skeleton of each individual (in comparison to vertebrae, for instance), or more liable to the destructive processes (e.g., ribs and metacarpals).

In a scenario with long transport of remains, it is expected more bones from the most transportable group (FTI $>75$ ) and minority/absence of less transportable bones (FTI $<50$ ), and the exact opposite for bones deposited at the place of death, i.e., dominance of less transportable and absence of those more transportable. Thereafter, this implies that an abundance of the intermediate group (FTI $=50-75)$ would correspond to the remains that had short transport. However, what does the abundance of little and very transportable bones mean? Spatial mixing. Bones that came from distant places associated with bones from near places clearly show spatial mixing. But this is not true for F3 cave.

The absence of hydraulic equivalence between bones and sediments suggests that the animals died near the cave and their remains were transported later into them. If the bones had been transported from other place, we should had found sediments of compatible granulometry with the bones, which we did not see. However, it is undeniable that the taxa represented in the F3 cave assemblage are not troglophiles and/or troglobies, i.e., they lived outside the cave. In other words, all bones of medium-sized and megammamals, independent of transportability group, undergone practically no transport from the place of death and the sediment carried from the surface is the same clay that fills the cave,

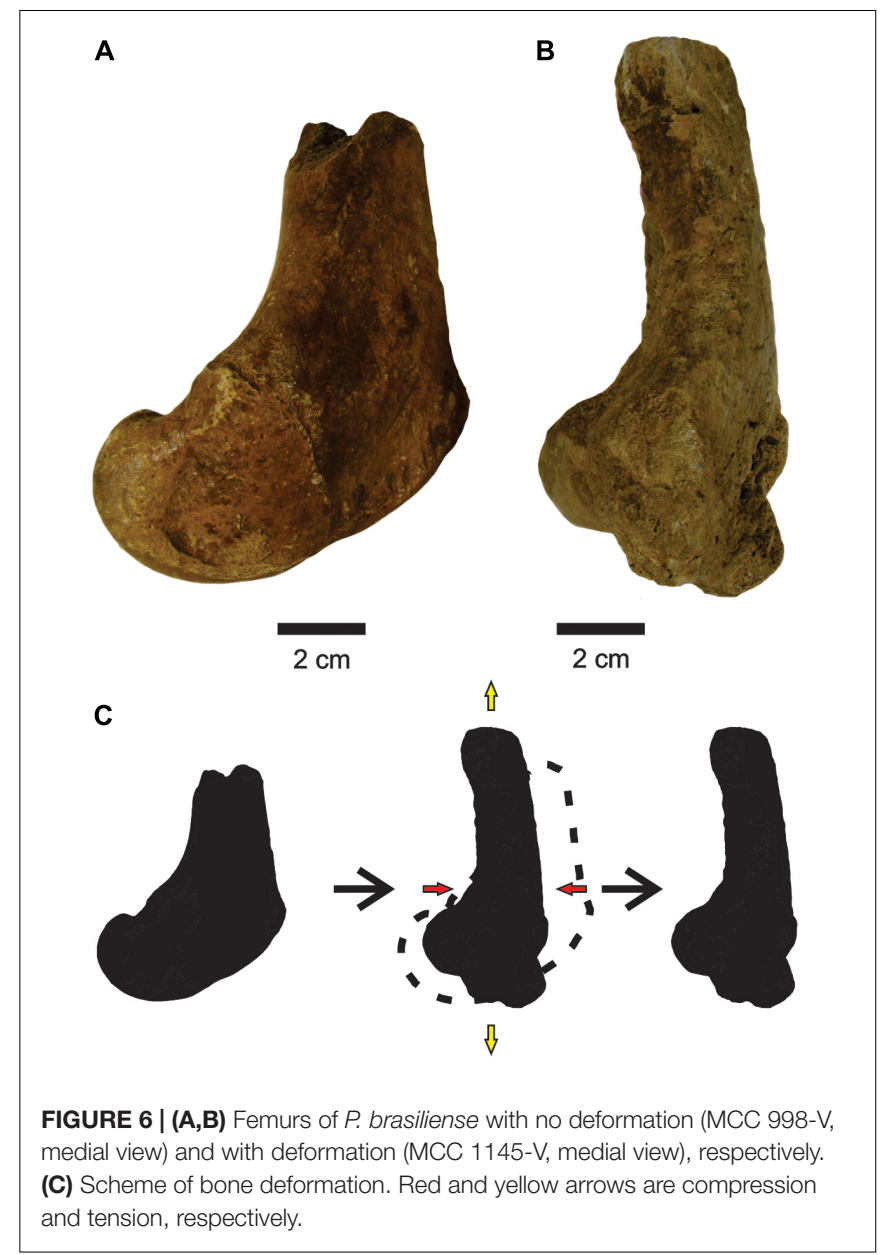

as a product of erosion from limestone. Therefore, the F3 cave assemblage is classified as in situ preserved, and spatial mixing is discarded.

The fragmentation of bones is marked by dominance of prefossildiagenetic breaks, and can be associated to disarticulation, weathering (Behrensmeyer, 1991), transport (Voorhies, 1969), synecological interactions (Shipman, 1981; Haynes, 1983), such predation and necrophagy, and falling rocks. However, as most fossils in F3 cave does not bear weathering or biogenic marks, and the transport was irrelevant (see above), most breaks can be attributed to disarticulation.

There is no information about fossils collected under collapsed blocks (Carvalho, 1966), and along with the rarefaction of deformed bones suggest that the action of compressive forces on the sediments or the collapsing of blocks were not common in F3. An exception to this is the femur of $P$. brasiliense (MCC $1145-\mathrm{V})$ that seems to have been crushed by impact, because the bone presents breaks along its surface and a deformed anatomy. In these cases, an eventual fall of a rock block was the most likely cause.

Abrasion may indicate transport of specimens when all surfaces are equally abraded (see Fernández-Jalvo and Andrews, 2016). In the fossils of F3 cave, abrasion marks are scarce, corroborating the absence or shortage of transport. In addition, 

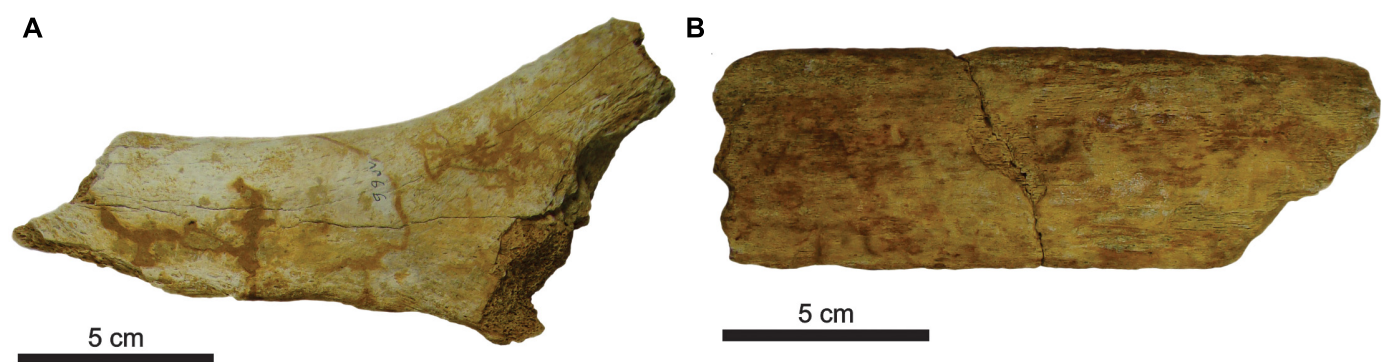

$5 \mathrm{~cm}$

C

D
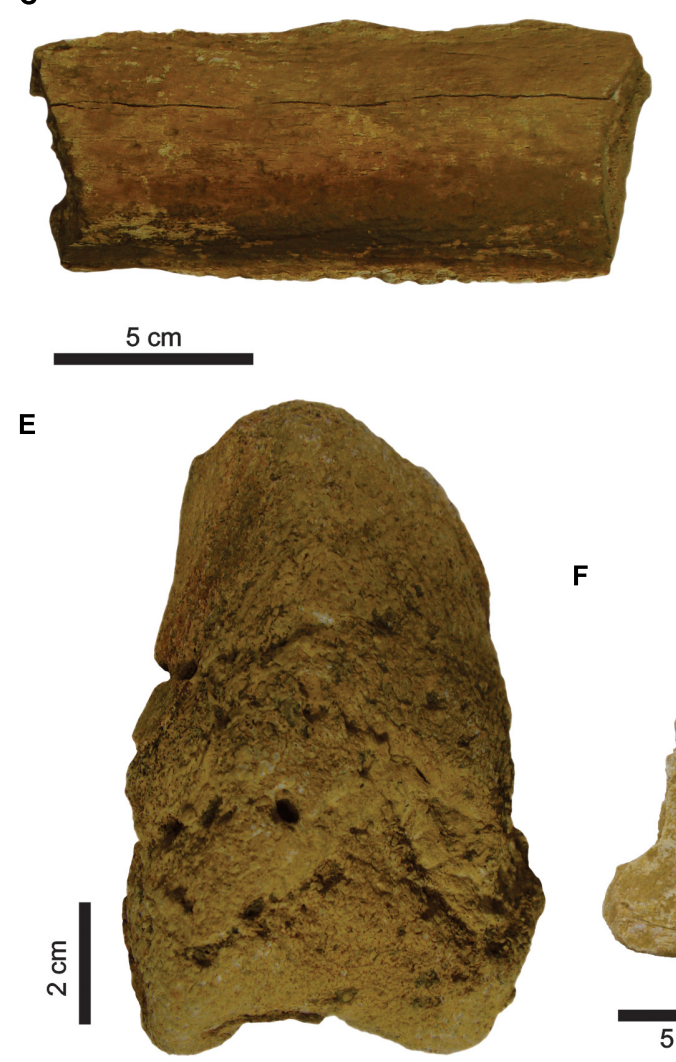

$\mathbf{F}$
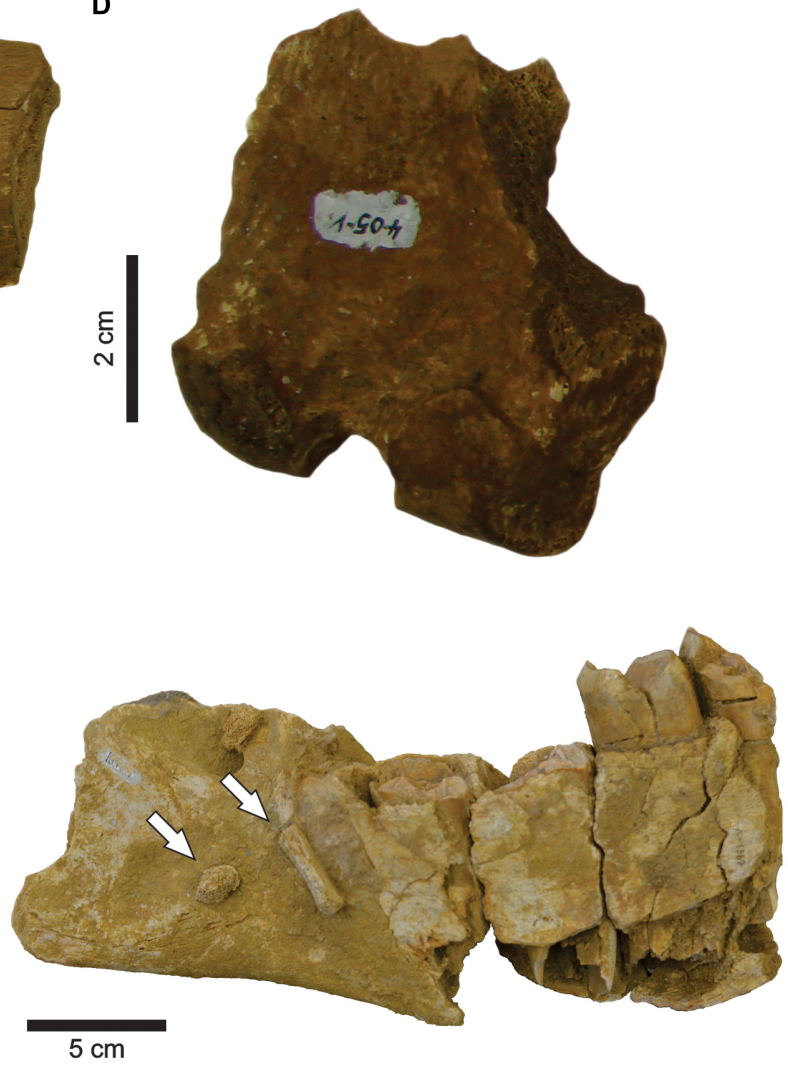

FIGURE 7 | (A-D) Are rib fragments of E. laurillardi. (A) Light yellow (MCC 990-V). (B) Medium yellow (MCC 829-V). (C) Dark yellow (MCC 805-V). (D) Very dark yellow (MCC 405-V). (E) Femur of $P$. brasiliense with mineral overgrowth (MCC 1141-V, anterior view). See Figure 6A for femur with no deformation. (F) Mandible of E. laurillardi (MCC 2891-V, lateral view) with Stage 1 of sediment and bone fragment incrustation (pointed by white arrows).

the few abrasion marks occur only on one side of the affected bones, suggesting that these bones were inert in the substrate or surface while exposed to sediment flows (Fernández-Jalvo and Andrews, 2016). In this scenario, the higher the intensity of the one-sided abrasion, the longer the bone was exposed to sediment flows, either outside or inside the cave.

Most fossils in the F3 cave do not show signs of corrosion likely because the deposit is filled by carbonate sediment and clasts (Carvalho et al., 1966), and, consequently, has high availability of carbonates associated with the terrigenous elements (see Simms, 1994), and because the low humidity during dry periods (Fernández-Jalvo and Andrews, 2016). As most bones had a quick burial, they are protected inside the sediment from the intermittent moisture. In contrast, the few bones with high levels of corrosive damage could indicate three situations (sensu Andrews, 1990; Fernández-Jalvo and Andrews, 2016) inside the F3 cave: (1) the bones were preserved in a wet soil, rich in organic acid; (2) the bones were preserved in an area closer to the cave entrance, and they were more susceptible to external corrosive agents; or (3) they had a delayed burial inside the cave, causing them to stay longer suffering the action of the infiltrating water or the humid atmosphere. The first and second hypotheses are unlike because if the soil were wet, corrosion would be pervasive, but it is scarce in the bones of the assemblage, and the entrance of F3 is at the roof of the cave, several meters above the fossiliferous sediment, and, consequently, far from the bones. The remaining explanation is that the unburied or partially buried remains were subjected to a humid atmosphere during eventual 

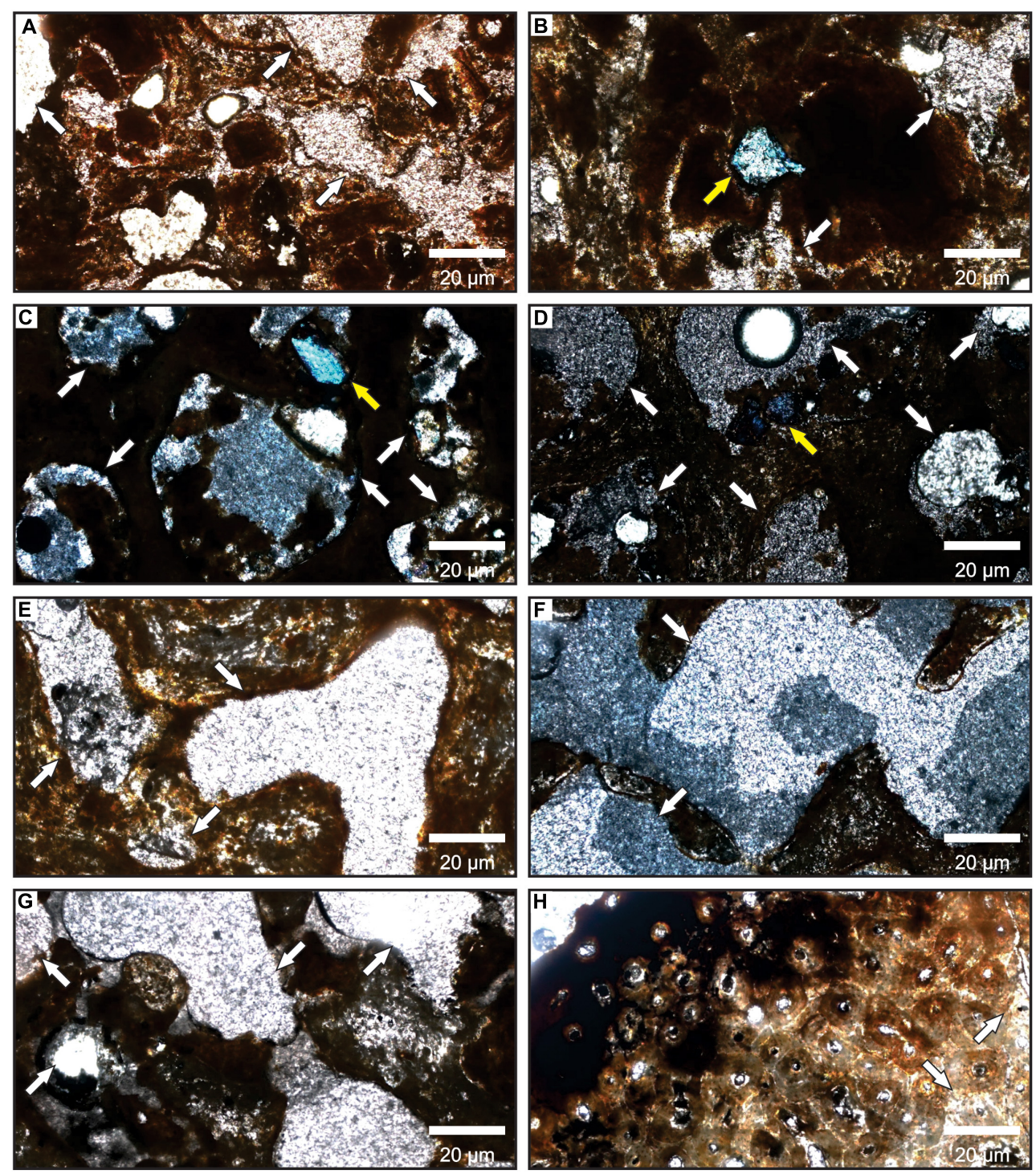

FIGURE 8 | Photomicrographs of the eight thin sections made from the bones of Mammalia indet. Note the rare or absent pore filling indicated by the white arrows. The yellow arrows in (B-D) few calcite crystals filling the pores. All photos have a 50X magnification. (A,E-H) in parallel nicols and (B-D) in crossed nicols.

wetter periods, a scenario supported by the bones presenting high stages of weathering.

\section{FOSSILDIAGENESIS}

The scarcity of permineralization and incrustation in fossils discards the presence of water in the sediments (Medeiros, 2010). However, the mineral ingrowth in a femur of $P$. brasiliense (MCC $1141-\mathrm{V})$ and the incrustation in a mandible of E. laurillardi (MCC 2891-V) indicate a condition of high moisture in the deposit. This could have happened if these bones were unburied during the fossildiagenis or they were exhumed in a humid period. As some bones present smooth/post-fossildiagenetic breaks, the exhumation happened to some fossils.

\section{CLIMATE VARIATION AND PRESERVATION}

The literature cites a transition from wetter condition in the Late Pleistocene to dry weather in the Greenlandian-Northgrippian (Wang et al., 2004; Novello et al., 2017), which supports climatic influence in the modes of preservation of fossils and the occurrence of taphonomic signatures in bones.

When we compare the frequency of corrosion and abrasion with the increase in weathering stages, we observe that almost half of bones always presents abrasion and corrosion marks. Concerning the fossils in weathering stage 0 , more than half of the bones have damage by abrasion up to stage 2 and corrosion reaching stage 3 . This implies that, despite being exposed for less than a year, these bones were inert through a 
TABLE 5 | Dimensions and anatomical positions of puncture marks.

\begin{tabular}{|c|c|c|c|c|c|}
\hline Specimen & Perforation & Largest diameter (cm) & Smallest diameter (cm) & Depth & Portion of bone \\
\hline \multirow[t]{2}{*}{ MCC 489-V } & Elliptical & 2.1 & 1.4 & 0.6 & Articular surface to pelvis \\
\hline & Elliptical & 0.9 & 0.6 & 0.6 & Articular surface to pelvis \\
\hline MCC 815-V & Elliptical & 3.5 & 3.3 & 3 & Articular surface to pelvis \\
\hline MCC 335-V & Elliptical & 1.8 & 1.5 & 1.2 & Medial portion \\
\hline MCC 102-V & Elliptical & 1.7 & 1.3 & 1.2 & Cranial articular surface \\
\hline MCC 144-V & Elliptical & 2.5 & 1.6 & 5.1 & Border of articular surface \\
\hline MCC 197-V & Four ellipticals & 0.5 a 0.9 & 0.4 a 0.5 & 0.2 a 0.3 & Articular surface \\
\hline \multirow[t]{2}{*}{ MCC 977-V } & Elliptical & 1.61 & 0.92 & 2.15 & Anterior surface of distal portion of diaphysis \\
\hline & Elliptical & 0.83 & 0.70 & 0.42 & Anterior surface of distal portion of diaphysis \\
\hline \multirow[t]{2}{*}{ MCC 161-V } & Elliptical & 0.79 & 0.61 & 1.20 & Articular surface of caudal portion \\
\hline & Elliptical & 1.40 & 1.29 & 0.80 & Articular surface of cranial portion \\
\hline MCC 455-V & Six ellipticals & 1.0 on average & 0.7 on average & 1.4 on average & Border of articulation \\
\hline
\end{tabular}

hydric flow that abraded them (Fernández-Jalvo and Andrews, 2016) during some wet periods, which allowed corrosion to occur (Andrews, 1990; Fernández-Jalvo and Andrews, 2016). The bones without abrasion and corrosion marks, probably were unburied during dry periods. The climate variations are not restricted to the interior of the cave, because the occurrence of tooth, insect and trample marks are conditioned by dry and wet cycles. All bones with insect marks were produced closer to or during a wet period, because they present abrasion and corrosion features. The absence of weathering marks in those specimens indicates a burial in less than a year (Behrensmeyer, 1978).

Concerning the trample marks, the dominance of the stages 0 of abrasion and corrosion indicates that most were made during a dry period. The bones that reached high levels of abrasion and corrosion belong to a humid period and undergone a rapid burial because they do not present weathering marks (Behrensmeyer, 1978).

In the dry periods, it is expected low provision of food, implying high mortality by starvation and increased scavenger activity. In the F3 cave assemblage, most bones with tooth marks are assigned to consumption after the animals' death, which could imply necrophagy during this period of food scarcity. Probably this scavenging was made by S. populator (Dantas et al., 2020) and P. troglodytes (Berta, 1989; Dantas et al., 2021), the predators that lived closer to F3 cave (Araújo-Júnior and Porpino, 2011; Araújo-Júnior et al., 2017a). It is important to mention that food stress was not exclusive to drought. Half of these bitten bones indicates preservation in dry conditions, because the scarcity of abrasion and corrosion marks, while the other half was subjected to a wet environment, due to the presence of corrosion and abrasion marks.

\section{TAPHONOMIC HISTORY OF F3 CAVE}

There are four taphonomic modes in the assemblage of F3 cave, which seems to be related to climate changes: (1) In mode 1, the bones were exposed during the dry cycle, presenting stages
0 of abrasion and corrosion; (2) In mode 2, the bones were exposed during the wet cycle, presenting stages 1 of abrasion and corrosion; (3) In mode 3, the bones were exposed through the dry and wet cycles, presenting weathering stages $1-3$, abrasion stage 2 and corrosion stages 2-3; and (4) mode 4 comprehend bones presenting tooth marks or trample marks or insect marks.

The animals died next to the F3 cave entrance, and their carcasses become exposed for a short time span before being transported into the cave. The disarticulation was the first process affecting the bones, excepting some parts of the carapace of Glyptotherium sp. and Pachyarmatherium brasiliense. Almost all bones were disarticulated in less than a year, whether inside or outside the cave. That is because the dominance of weathering stage 0 suggests that the bones had to be buried before 1 year after the animal's death (Behrensmeyer, 1978; Behrensmeyer and Miller, 2012).

After disarticulation, there are three possible scenarios. In the first, which comprehends the preservation mode of most specimens, the bones were buried in less than a year during a dry period. The remains did not had contact with moisture and hydric flows, protecting them from corrosion and abrasion. Nonetheless, few bones were bitten or trampled before getting into the cave.

In the second scenario, the bones also were buried in less than a year, but abrasion and corrosion marks made by hydric flows and moisture imply a preservation during a wet period. During this humid phase a few bones were attacked by insects. The third scenario involves the minority of bones, which become exposed for over a year. As they were not exposed only to a climate cycle, these bones developed weathering marks up to stage 4 due to dryness and humidification. The presence of abrasion stage 2 and corrosion stages 2-3 supports the hypothesis of a long contact or more than one contact with moisture.

\section{CONCLUSION}

Most animals died near the entrance of F3 cave, but without significative transport, characterizing the deposit as an in situ- 
preserved assemblage. The dominance of fossils of Eremotherium laurillardi is due to their high structural resistance and to the abundance of this taxon in the Pleistocene assemblages of RIB.

The disarticulation of almost all bones took less than a year, and most bones were buried in less than a year during a dry period, which is evidenced by the rarefaction of weathering, abrasion and corrosion marks. However, some bones presenting corrosion and abrasion marks indicates that some fossils were preserved during a wet period and, therefore, are indicative of time-averaging in the assemblage.

The tooth marks suggest necrophagy and they are present in bones that were preserved during dry and wet cycles, indicating scarcity of food. Fossils presenting post-diagenetic breakages reveal that few bones were exhumed, being susceptible to hydric inflows during the wet cycle.

\section{DATA AVAILABILITY STATEMENT}

The original contributions presented in the study are included in the article/supplementary material, further inquiries can be directed to the corresponding author.

\section{REFERENCES}

Andrews, P. (1990). Owls, Caves, and Fossils. London: The Natural History Museum.

Andrews, P., and Cook, J. (1985). Natural modifications to bones in a temperate setting. Man 20, 675-691. doi: 10.2307/2802756

Araripe, P. T., and Feijó, F. J. (1994). Potiguar Basin; Bacia Potiguar. Bol. Geociênc. Petrobras 8, 127-141.

Araújo-Júnior, H. I. (2016). Classifying vertebrate assemblages preserved in Quaternary tank deposits: implications for vertebrate taphonomy and paleoecology. Palaeogeogr. Palaeoclimatol. Palaeoecol. 445, 147-152. doi: 10. 1016/j.palaeo.2015.12.025

Araújo-Júnior, H. I., and Bissaro-Júnior, M. C. (2017). “Tafonomia de vertebrados em ambientes continentais," in Tafonomia: Métodos, Processos e Aplicação, eds R. S. Horodyski and F. Erthal (Curitiba: Editora CRV), 175-236.

Araújo-Júnior, H. I., Barbosa, F. H. S., and Silva, L. H. M. (2017a). Overlapping paleoichnology, paleoecology and taphonomy: analysis of tooth traces in a Late Pleistocene-early Holocene megafaunal assemblage of Brazil and description of a new ichnotaxon in hard substrate. Palaeogeogr. Palaeoclimatol. Palaeoecol. 468, 122-128. doi: 10.1016/j.palaeo.2016.12.007

Araújo-Júnior, H. I., Porpino, K. O., and Bergqvist, L. P. (2017b). Origin of bonebeds in Quaternary tank deposits. J. S. Am. Earth Sci. 76, 257-263. doi: 10.1016/j.jsames.2017.03.012

Araújo-Júnior, H. I., and Porpino, K. O. (2011). Assembleias fossilíferas de mamíferos do Quaternário do Estado do Rio Grande do Norte, Nordeste do Brasil: diversidade e aspectos tafonômicos e paleoecológicos. Pesqui. Geociênc. 38, 67-83. doi: 10.22456/1807-9806.23836

Araújo-Júnior, H. I., Porpino, K. O., and Bergqvist, L. P. (2015). Vertebrate taphonomy and paleoecology in an Upper Pleistocene tank deposit of Paraíba, Brazil: taphonomic modes, evidence of temporal and spatial resolutions and paleoecological patterns of the Brazilian Intertropical Region. Palaeogeogr. Palaeoclimatol. Palaeoecol. 437, 1-17. doi: 10.1016/j.palaeo.2015. 07.009

Araújo-Júnior, H. I., Porpino, K. O., Ximenes, C. L., and Bergqvist, L. P. (2013). Unveiling the taphonomy of elusive natural tank deposits: a study case in the

\section{AUTHOR CONTRIBUTIONS}

LT collected and analyzed the data and elaborated Figures 2-8 and the tables. FB elaborated Figure 1. All authors wrote the introduction, geological setting, materials and methods, results, discussion, and conclusion.

\section{ACKNOWLEDGMENTS}

We are grateful to Museu Câmara Cascudo of Universidade Federal do Rio Grande do Norte (MCC/UFRN) by allowing the study of the specimens. LT and HA-J thank to the financial support provided by Fundação de Amparo à Pesquisa do Estado do Rio de Janeiro (FAPERJ; processes E-26/203.131/2016 and E26/203.176/2017, respectively). HA-J and KP thank to Conselho Nacional de Desenvolvimento Científico e Tecnológico (CNPq; processes n. 301405/2018-2 and 310206/2018-9, respectively). HA-J also thanks to Rio de Janeiro State University (Prociencia grant: 38944-5). We also are grateful to Ariane Felix for the drawing of the cave sketch. Finally, we thank the reviewers EO and EJ-H for the comments and suggestions that helped to improve the manuscript. We acknowledge the financial support from Pró-reitoria de Extensão e Cultura (PR3) - UERJ for the payment of the publication fee.

Pleistocene of northeastern Brazil. Palaeogeogr. Palaeoclimatol. Palaeoecol. 378, 52-74. doi: 10.1016/j.palaeo.2013.04.001

Auler, A. S., Piló, L. B., Smart, P. L., Wang, X., Hoffmann, D., Richards, D. A., et al. (2006). U-series dating and taphonomy of Quaternary vertebrates from Brazilian caves. Palaeogeogr. Palaeoclimatol. Palaeoecol. 240, 508-522. doi: 10. 1016/j.palaeo.2006.03.002

Barbosa, F. H. S. (2013). Análise Paleopatológica em Mamíferos Pleistocênicos do Lajedo da Escada, Rio Grande do Norte, Brasil. Ph.D. dissertation. Recife: Universidade Federal do Pernambuco.

Barbosa, F. H. S., Porpino, K. O., Fragoso, A. B. L., and Oliveira, E. V. (2014). Arthritis in a Glyptodont (Mammalia, Xenarthra, Cingulata). PLoS One 9:e88646. doi: 10.1371/journal.pone.0088646

Behrensmeyer, A. K. (1975). The taphonomy and paleoecology of Plio-Pleistocene vertebrate assemblages east of Lake Rudolf, Kenya. Bull. Mus. Comp. Zool. 146, 473-578.

Behrensmeyer, A. K. (1978). Taphonomic and ecologic information from bone weathering. Paleobiology 4, 150-162. doi: 10.1017/S0094837300005820

Behrensmeyer, A. K. (1991). “Terrestrial vertebrate accumulations," in Taphonomy: Releasing the Data Locked in the Fossil Record, eds P. A. Allison and D. E. G. Briggs (New York, NY: Plenum), 291-335. doi: 10.1007/978-1-4899-5034-5_6

Behrensmeyer, A. K., and Miller, J. H. (2012). "Building links between Ecology and Paleontology using taphonomic studies of recent vertebrate communities," in Paleontology in Ecology and Conservation, ed. J. Louys (Berlin: Springer-Verlag), 69-91. doi: 10.1007/978-3-642-25038-5_5

Berta, A. (1989). Quaternary Evolution and Biogeography of the Large South American Canidae (Mammalia: carnivora). Ph.D. thesis. Berkeley CA: University of California.

Buchmann, R., Guimarães, M. S., Rocha-dos-Santos, B. C. A., Pinheiro, R. S., Rotti, A., Ávilla, L. S., et al. (2017). Mamíferos fósseis do Quaternário da Gruta Tacho de Ouro, Tocantins, Norte do Brasil: Diversidade, tafonomia e aspectos paleoicnológicos e paleoambientais. Rev. Bras. Paleontol. 20, 203-218. doi: $10.4072 /$ rbp.2017.2.05

Bunn, H. T. (1981). Archaeological evidence for meat-eating by Plio-Pleistocene hominids from Koobi Fora and Olduvai Gorge. Nature 291, 574-577. doi: $10.1038 / 291574 \mathrm{a} 0$ 
Cartelle, C. (1999). "Pleistocene mammals of the Cerrado and Caatinga of Brazil," in Mammals of the Neotropics: The Central Neotropics, eds J. F. Eisenberg and K. H. Redford (Chicago, IL: The University of Chicago Press), $27-46$.

Cartelle, C. (2012). "Um pouco de história," in Das grutas à luz: Os mamíferos pleistocênicos de Minas Gerais, ed. C. Cartelle (Belo Horizonte: Bicho do Mato Editora), 14-45.

Carvalho, J. N. C. (1966). Considerações Sobre a Fauna Pleistocênica do Lajedo da Escada: Arquivos do Instituto de Antropologia de Natal 2, Natal. (Lagoa Nova: Universidade Federal do Rio Grande do Norte), 303-313.

Carvalho, J. N. C., Campos-e-Silva, A., Vasconcelos, M. D. T., Oliveira, L. D. D., and Silva, D. D. (1966). Informação Sobre a jazida Fossilifera Pleistocênica do Lajedo da Escada, Município de Mossoró, Rio Grande do Norte. Arquivos do Instituto de Antropologia de Natal, 2. (Lagoa Nova: UFRN), 392-395.

CECAVCentro Nacional de Pesquisa e Conservação de Cavernas [CECAV] (2020). Anuário estatístico do patrimônio espeleológico brasileiro 2020. Brasília: Instituto Chico Mendes de Conservação da Biodiversidade (ICMbio).

Damasceno, J. M. (1973). Ocorrência de Toxodon platensis Owen, 1840 em Olho d'água da Escada, Município de Mossoró, Rio Grande do Norte. Arq. Inst. Antropol. Natal 1, 1-18.

Dantas, M. A. T., Bernardes, C., Asevedo, L., Pansani, T. R., França, L. M., Aragão, W. S., et al. (2021). Isotopic palaeoecology $(813 \mathrm{C})$ of three faunivores from Late Pleistocene of the Brazilian intertropical region. Hist. Biol. 33, 1-8. doi: 10.1080/08912963.2021.1933468

Dantas, M. A. T., Cherkinsky, A., Bocherens, H., Drefahl, M., Bernardes, C., and França, L. M. (2017). Isotopic paleoecology of the Pleistocene megamammals from the Brazilian Intertropical Region: feeding ecology (d13C), niche breadth and overlap. Quat. Sci. Rev. 170, 152-163. doi: 10.1016/j.quascirev.2017. 06.030

Dantas, M. A. T., Cherkinsky, A., Lessa, C. M. B., Santos, L. V., Cozzuol, M. A., Omena, É. C., et al. (2020). Isotopic paleoecology $(\delta 13 \mathrm{C}, \delta 18 \mathrm{O})$ of a late Pleistocene vertebrate community from the Brazilian Intertropical Region. Rev. Bras. Paleontol. 23, 138-152. doi: 10.4072/rbp.2020.2.05

Dantas, M. A. T., Dutra, R. P., Cherkinsky, A., Fortier, D. C., Kamino, K. H. Y., Cozzuol, M. A., et al. (2013). Paleoecology and radiocarbon dating of the Pleistocene megafauna of the Brazilian Intertropical Region. Quat. Res. 79, 61-65. doi: 10.1016/j.yqres.2012.09.006

Eberth, D. A., Rogers, R. R., and Fiorillo, A. R. (2007). "A Pratical Approach to the Study of Bonebeds," in Bonebeds: Genesis, Analysis and Paleobiological Significance, eds R. R. Rogers, D. A. Eberth, and A. R. Fiorillo (Chicago, IL: The University of Chicago Press), 265-332.

Fernández-Jalvo, Y., and Andrews, P. (2016). Atlas of Taphonomic Identifications. Dordrecht: Springer. doi: 10.1007/978-94-017-7432-1

Fernández-Jalvo, Y., Scott, L., and Andrews, P. (2010). Taphonomy in paleoecological interpretations. Quat. Sci. Rev. 30, 1292-1302. doi: 10.1016/j. quascirev.2010.07.022

Fiorillo, A. R. (1987). Trample marks: caution from the Cretaceous. Curr. Res. Pleistocene 4, 73-75.

Fiorillo, A. R. (1988). Taphonomy of Hazard Homestead Quarry (Ogallala Group), Hitchcock County, Nebraska. Contrib. Geol. 26, 57-97.

Fiorillo, A. R. (1989). "An experimental study of trampling: implications for the fossil record," in Bone Modification, eds R. Bonnichsen and M. H. Sorg (Orono, ME: University of Maine), 61-72.

Frison, G. C., and Todd, L. C. (1986). "Taphonomic study of the Colby Site mammoth bones," in The Colby Mammoth Site: Taphonomy and Archaeology of a Clovis Kill in Northern Wyoming, ed. G. C. Frison (Albuquerque, NM: University of New Mexico Press).

Gasparini, G. M., Holanda, E. C., Araújo-Júnior, H. I., and Ávilla, L. S. (2015). A Quaternary very Young juvenile Tapirus Brisson, 1762 (Mammalia, Perissodactyla) from a cave deposit in northern Brazil: taxonomy and taphonomy. Hist. Biol. 28, 803-811. doi: 10.1080/08912963.2015.1035269

Haynes, G. (1980). Evidence of carnivore gnawing on Pleistocene and Recent mammalian bones. Paleobiology 6, 341-351. doi: 10.1017/S0094837300006849

Haynes, G. (1982). Utilization and skeletal disturbances of North American prey carcasses. Arctic 35, 266-281. doi: 10.14430/arctic2325

Haynes, G. (1983). A guide for differentiating mammalian carnivore taxa responsible for gnaw damage to herbivore limb bones. Paleobiology 9, 164-172. doi: $10.1017 /$ S0094837300007545
Holz, M., and Simões, M. G. (2002). Elementos Fundamentais de Tafonomia. Porto Alegre: Editora da Universidade/UFRGS.

Hunt, R. M. (1978). Depositional setting of a Miocene mammal assemblage, Sioux County, Nebraska (U.S.A.). Palaeogeogr. Palaeoclimatol. Palaeoecol. 24, 1-52. doi: 10.1016/0031-0182(78)90006-8

Lyman, R. L. (1994). Vertebrate Taphonomy. Cambridge: Cambridge University Press. doi: $10.1017 / \mathrm{CBO} 9781139878302$

Macdonald, J., and Terrell-Nield, C. E. (1989). What happens to animals when they die in caves? Cave Sci. 16:115.

Maldonado, V., Monteiro, L. G. P., Rotti, A., Pereira, C., Araújo-Júnior, H. I., and Avilla, L. S. (2016). Taphonomic aspects of deer (Mammalia, Cetartiodactyla, Cervidae) remains from a Quaternary cave deposit in Northern Brazil. J. Sediment. Environ. 1, 234-248. doi: 10.12957/jse.2016.23026

Medeiros, M. A. (2010). "Fossildiagênese," in Paleontologia: Conceitos e Métodos, ed. I. S. Carvalho (Rio de Janeiro: Editora Interciência), 65-77.

Munsell, A. H. (1994). Munsell Soil Color Charts (Revised Edition). New Windsor, NY: Macbeth Divison of Kollmorgen Instruments Corporation.

Novello, V. F., Cruz, F. W., Vuille, M., Stríkis, N. M., Lawrence-Edwards, R., Cheng, H., et al. (2017). A high-resolution history of the South American Monsoon from Last Glacial Maximum to the Holocene. Sci. Rep. 7:44267. doi: $10.1038 /$ srep 44267

Oliveira, É. V., Porpino, K. O., and Barreto, A. F. (2010). On the presence of Glyptotherium in the Late Pleistoceneof Northeastern Brazil, and the status of "Glyptodon" and"Chlamydotherium". Paleobiogeographic implications. Neues Jahrb. Geol. Paläontol. 258, 353-363. doi: 10.1127/0077-7749/2010/0116

Oliveira, L. D. D. (1986). "Considerações sobre a ocorrência de paleolama major (Liais, 1872) no quaternário do Rio Grande do Norte," in Proceedings of the 1986 XII Simpósio de Geologia do Nordeste, João Pessoa.

Pessoa-Neto, O. C., Soares, U. M., Silva, J. G. F., Roesner, E. H., Florencio, C. P., and Souza, C. A. V. (2007). Bacia Potiguar. Bol. Geociênc. Petrobras 15, 357-369.

Porpino, K. O., Fernicola, J. C., and Bergqvist, L. P. (2009). A new cingulate (Mammalia: Xenarthra), Pachyarmatherium brasiliense sp. nov., from the Late Pleistocene of Northeastern Brazil. J. Vertebr. Paleontol. 29, 881-893. doi: 10. $1671 / 039.029 .0305$

Porpino, K. O., and Santos, M. F. C. F. (2003). "Novos registros de artiodactyla e perissodactyla para o lajedo de escada, Baraúnas/RN," in Proceedings of the 2003 XVIII Congresso Brasileiro de Paleontologia, Brasilia.

Porpino, K. O., Santos-Jr, V., and Santos, M. F. C. F. (2007). "Lajedo de Soledade, Apodi, State of Rio Grande do Norte - A remarkable megafauna site from northeastern Brazil," in Sítios Geológicos e Paleontológicos do Brasil, eds M. Winge, C. Schobbenhaus, C. R. G. Souza, A. C. S. Fernandes, M. Berbert-Born, and E. T. Queiroz (Rimini: SIGEP).

Ribeiro, R. C., Araújo-Júnior, H. I., Kinoshita, A., Figueiredo, A. M. G., Baffa, O., and Carvalho, I. S. (2014). "How much time is represented in the fossil record of tank deposits?," in Paleontologia em Destaque, eds T. R. Simões, R. G. Figueiredo, R. Delcourt, and T. Rodrigues (Vitória: Boletim do IX Simpósio Brasileiro de Paleontologia de Vertebrados) 115.

Ribeiro, R. C., Kinoshita, A., Araújo-Júnior, H. I., Figueiredo, A. M. G., Carvalho, I. S., and Baffa, O. (2021). ESR dating of Toxodon teeth from Baixa Grande, Bahia, Brazil. J. South Am. Earth Sci. 112:103616. doi: 10.1016/j.jsames.2021. 103616

Santos, M. F. C. F., Bergqvist, L. P., Lima-Filho, F. P., and Pereira, M. M. V. (2002). Feições tafonômicas observadas em fósseis pleistocênicos do Rio Grande do Norte. Rev. Geol. 15, 31-41.

Shipman, P. (1981). Life History of a Fossil: An Introduction to Taphonomy and Paleoecology. Cambridge, MA: Harvard University Press.

Silva, J. L. L. (2008). Reconstrução Paleoambiental Baseada no Estudo de Mamíferos Pleistocênicos de Maravilha e Poço das Trincheiras, Alagoas, Nordeste do Brasil. Ph.D. thesis. Recife: Universidade Federal de Pernambuco.

Silva, R. C., Berbert-Born, M., Bustamante, D. E. F., Santoro, T. N., Sedord, F., and Avilla, L. S. (2019a). Diversity and preservation of Pleistocene tetrapods from caves of southwestern Bahia, Brazil. J. South Am. Earth Sci. 90, 233-254. doi: 10.1016/j.jsames.2018.12.004

Silva, J. A., Leal, L. A., Cherkinsky, A., and Dantas, M. A. T. (2019b). Late Pleistocene meso-megamammals from Anagé, Bahia, Brazil: taxonomy and isotopic paleoecology (813C). J. South Am. Earth Sci. 96:102326. doi: 10.1016/j. jsames.2019.102362 
Simms, M. J. (1994). Emplacement and preservation of vertebrates in caves and fissures. Zool. J. Linn. Soc. 112, 261-283. doi: 10.1111/j.1096-3642.1994.tb00 320.x

Simões, M. G., Rodrigues, S. C., and Bertoni-Machado, C. (2010). "Procedimentos metodológicos em Tafonomia," in Paleontologia: Conceitos e Métodos, ed. I. S. Carvalho (Rio de Janeiro: Editora Interciência), 413-430.

Souza-Cunha, F. L. (1966). Explorações paleontológicas no Pleistoceno do Rio Grande do Norte. Arq. Inst. Antropol. Natal 1-2, 75-116.

Vasconcelos, A. G., Kraemer, B. M., and Meyer, K. E. B. (2018). Tafonomia em cavernas brasileiras: histórico e métodos de coleta de fósseis preservados em solo carbonatado. Terr. Didatica 14, 49-68. doi: 10.20396/td.v14i1.8652042

Vasconcelos, A. G., Meyer, K. E. B., and Campello, M. S. (2015). Mamíferos quaternários das cavidades ES-08, município de Prudente de Morais, Minas Gerais: análises tafonômica e taxonômica. Rev. Bras. Paleontol. 18, 171-190. doi: 10.4072/rbp. 2015.1.12

Voorhies, M. R. (1969). Taphonomy and populations dynamics of an early Pliocene vertebrate fauna, Knox County, Nebraska. Contrib. Geol. 1, 1-69. doi: 10.2113/gsrocky.8.special_paper_1.1

Wang, X., Auler, A. S., Lawrence-Edwards, R., Cheng, H., Cristalli, P. S., Smart, P. L., et al. (2004). Wet periods in northeastern Brazil over the past $210 \mathrm{kyr}$ linked to distant climate anomalies. Nature 432, 740-743. doi: 10.1038/nature0 3067
Xing, L., Roberts, E. M., Harris, J. D., Gingras, M. K., Ran, H., Zhang, J., et al. (2013). Novel insect traces on a dinosaur skeleton from the Lower Jurassic Lufeng Formation of China. Palaeogeogr. Palaeoclimatol. Palaeoecol. 388, 58-68. doi: 10.1016/j.palaeo.2013. 07.028

Conflict of Interest: The authors declare that the research was conducted in the absence of any commercial or financial relationships that could be construed as a potential conflict of interest.

Publisher's Note: All claims expressed in this article are solely those of the authors and do not necessarily represent those of their affiliated organizations, or those of the publisher, the editors and the reviewers. Any product that may be evaluated in this article, or claim that may be made by its manufacturer, is not guaranteed or endorsed by the publisher.

Copyright (C) 2022 Trifilio, Araújo-Júnior, Porpino and Barbosa. This is an openaccess article distributed under the terms of the Creative Commons Attribution License (CC BY). The use, distribution or reproduction in other forums is permitted, provided the original author(s) and the copyright owner(s) are credited and that the original publication in this journal is cited, in accordance with accepted academic practice. No use, distribution or reproduction is permitted which does not comply with these terms. 